\title{
Stand species composition as a key factor determining the amount of polycyclic aromatic hydrocarbons (PAHs) in forest soils
}

\author{
Stanisław Łyszczarz ${ }^{1}$, Jarosław Lasota ${ }^{1}$, and Ewa Błońska ${ }^{1}$ \\ ${ }^{1}$ Uniwersytet Rolniczy im Hugona Kollataja w Krakowie
}

February 15, 2021

\begin{abstract}
The aim of the study was to determine the effect of stand species composition on PAHs accumulation. The study covered the soils of the stands of the Rybnik Forest District, which are under the influence of one of the highest deposition of industrial emissions in Europe. Pine, pine-oak and oak stands growing in the same soil conditions were selected for the study. Samples for further analyses were collected from the organic horizon, from the humus mineral horizon and from the mineral horizon. Organic $\mathrm{C}$ content, $\mathrm{N}$ content, $\mathrm{pH}$, alkaline cation content, as well as microbiological biomass of $\mathrm{C}$, $\mathrm{N}$, extracellular and intracellular enzyme activity were determined in the soil samples. PAH content was determined in the soil samples. Additionally, the soil organic matter fractions were determined: free light fraction (fLF), occluded light fraction (oLF) and mineral associated fraction (MAF). Pine stand soils were characterized by the highest average PAHs content. The oak stand soils were characterized by the lowest PAHs accumulation and high enzymatic activity. The study confirms the important role of the stand species composition in shaping the quality and quantity of SOM and soil acidification, which in turn is reflected in microbial activity and PAHs accumulation in forest soils. PAHs accumulation in forest soils is related to the fractional composition of SOM, which is the effect of the influence of species composition through the supplied aboveground and belowground biomass. A strong correlation between the PAH content and C content of the light soil fraction of OM was noted.
\end{abstract}

Stand species composition as a key factor determining the amount of polycyclic aromatic hydrocarbons (PAHs) in forest soils

Stanisław Łyszczarz ${ }^{* 1}$, Jarosław Lasota ${ }^{1}$, Ewa Błońska ${ }^{1}$

${ }^{1}$ Department of Ecology and Silviculture, Faculty of Forestry, University of Agriculture in Krakow, 29 Listopada 46, 31-425 Kraków, Poland

* Corresponding author. E-mail address: stanislaw.lyszczarz@student.edu.urk.pl (S. Lyszczarz)

\section{Acknowledgements}

This work was supported by the Ministry of Science and Higher Education of the Republic of Poland (SUB/040012/D019; A401, A408).

\section{Abstract}

The aim of the study was to determine the effect of stand species composition on PAHs accumulation. The study covered the soils of the stands of the Rybnik Forest District, which are under the influence of one of the highest deposition of industrial emissions in Europe. Pine, pine-oak and oak stands growing in the same soil conditions were selected for the study. Samples for further analyses were collected from the organic horizon, from the humus mineral horizon and from the mineral horizon. Organic $\mathrm{C}$ content, $\mathrm{N}$ content, $\mathrm{pH}$, alkaline cation content, as well as microbiological biomass of $\mathrm{C}, \mathrm{N}$, extracellular and intracellular enzyme activity were determined in the soil samples. PAH content was determined in the soil samples. Additionally, the 
soil organic matter fractions were determined: free light fraction (fLF), occluded light fraction (oLF) and mineral associated fraction (MAF). Pine stand soils were characterized by the highest average PAHs content. The oak stand soils were characterized by the lowest PAHs accumulation and high enzymatic activity. The study confirms the important role of the stand species composition in shaping the quality and quantity of SOM and soil acidification, which in turn is reflected in microbial activity and PAHs accumulation in forest soils. PAHs accumulation in forest soils is related to the fractional composition of SOM, which is the effect of the influence of species composition through the supplied aboveground and belowground biomass. A strong correlation between the PAH content and C content of the light soil fraction of OM was noted.

Keywords: enzyme activity; organic contamination; soil organic matter; PAHs; forest soils degradation

\section{Introduction}

Polycyclic aromatic hydrocarbons (PAHs) are organic compounds composed of two or more interconnected benzene rings causing soil environment contamination (Sun et al., 2012; Ghosal et al., 2016; Cao et al., 2020). The prevalence of PAHs in the soil environment is mostly of anthropogenic origin (Zhou et al., 2005), due to the increasing use of energy from the combustion of fossil fuels, oil and internal combustion engines (Tiwari et al., 2011; Lui et al., 2017). As a result of the sorption capacity of soils, nearly $90 \%$ of total PAHs emissions present in the ecosystem are accumulated (Eom et al., 2007). In forest soils, organic pollutants are stored, captured and delivered to the litter by tree crowns (Matzner, 1984). The accumulation of PAHs in soils depends in particular on the amount and quality of soil organic matter and soil $\mathrm{pH}$ (Chaineau et al., 2005; Wu et al., 2008; Lladó et al., 2009; Aichner et al., 2015). As a result of the impact of woody vegetation, forest soils are characterized by a high content of organic carbon, which is reflected in a higher accumulation of PAHs compared to agricultural soils. In addition to soil organic matter, $\mathrm{pH}$ and fine fraction content is important in the accumulation of PAHs in the soil environment (Luo et al., 2008). The $\mathrm{pH}$ value is an important parameter in the PAH biodegradation process as it is a key factor for the availability of nutrients and thus for the development of microorganisms involved in PAHs degradation. The amount and quality of organic matter of forest soils is determined by the species composition of the stand (De Deyn et al., 2008; Błońska et al., 2016; Błońska et al., 2017). The stand, through litter fall and root systems, shapes soil pH and soil chemical properties (Reich et al., 2005; Mareschal et al., 2010). Coniferous stands soils have a lower $\mathrm{pH}$ compared to mixed or deciduous stands soils (Jandl et al., 2004). Strong soil acidification results in a reduction of sorption capacity, causing reduced biological activity and disruption of $\mathrm{C}, \mathrm{N}$ and $\mathrm{P}$ cycle in the forest ecosystem (Mueller et al., 2012). The fall of litter in deciduous stands has a positive effect on soil $\mathrm{pH}$ and provides macroelements to improve biological activity of forest soils and faster circulation of organic matter (Hobbie et al., 2007; Błońska et al., 2016).

The soil organic matter, due to its heterogeneous structure and composition, shows strong sorption properties for most of the persistent organic pollutants, in particular PAHs (Ehlers \& Loibner, 2006; UkalskaJaruga et al., 2015). Three fractions of soil organic matter are distinguished: free light fraction (fLF), aggregate-occluded light fraction (oLF) and mineral associated fraction (MAF) (Wambsganss et al., 2017). The fractional composition of soil organic matter determines its sorption capacity (Six et al., 2002). Labile $\mathrm{C}$ can remain in the ground from a week to years and recalcitrant $\mathrm{C}$ can persist for decades or even centuries. SOM associated with minerals can be stabilized due to its protection from mineralization, whereas the light fraction is more susceptible to changes to soil use and altered litter inputs (Grüneberg et al. 2013; Li et al. 2019a). Identification of SOM fraction can serve as an indicator of changes in store carbon (Błońska et al. 2017).

The processes of soil organic matter decomposition depend on the diversity and activity of soil microorganisms. The primary decomposers (bacteria and fungi) release extracellular hydrolytic enzymes into their immediate environment and these catalyze organic matter decomposition (Berg \& McClaugherty, 2008). Enzymatic activity informs about the condition of the soil environment and the activity of soil microorganisms (Gil-Sotres et al., 2005; Li et al., 2019b). Soil microorganisms and enzymes secreted by them are responsible for the circulation of basic nutrients such as C, N and P (Makoi \& Ndakidemi, 2008). Thanks to microorganisms and their enzymes, toxic organic compounds such as PAHs are removed from the soil environment 
(Haritash \& Kaushik, 2009). Biodegradation of these pollutants depends primarily on the moisture, $\mathrm{pH}$, soil temperature and bioavailability of organic matter contained in the soil (Johnsen et al., 2005). The biological breakdown of persistent, organic pollutants by microorganisms is one of the most important and effective methods of removing PAHs from the environment. The rate of biodegradation changes is influenced by the composition and activity of the microorganisms, the properties and age of the contamination, the presence of other compounds and the physical and chemical properties of the environment (Lors et al. 2012).

The aim of the study was to determine the effect of stand species composition on PAH accumulation in forest soils. Pine, pine-oak and oak stands growing on the same soil conditions were selected for the study. The following hypotheses were tested during the study: 1) stand species composition through the amount and quality of soil organic matter and soil acidification influences the PAHs accumulation; 2) deciduous species positively influence the soil enzymatic activity as a result increasing the PAHs degradation; 3) PAHs accumulation in forest soils is related to the fractional composition of soil organic matter.

\section{Materials and methods}

Study area and soil sampling

The study was conducted in the Rybnik Forest District of southeastern Poland (5005'55"N; 18deg32'42"E) (Fig. 1). The average annual temperature in this area was $8.4 \mathrm{degC}$ and the average annual rainfall was 705 $\mathrm{mm}$. The field sites were located in an area where the soils derived from glacial sand; they are dominated by Brunic Arenosols (WRB 2015). The Rybnik Forest District was located in one of the most exposed areas of industrial emissions in Europe (Fig. 2) (EEA 2020). The average annual concentrations of benzo(a)pyrene $[\mathrm{BaP}]$ for the Rybnik Forest District for the years 2017-2026, exceeded the admissible standards according to the Directive 2004/107/EC $\left(1 \mathrm{ng} \cdot \mathrm{m}^{3}\right.$ ) reaching the result in the range of $5-12 \mathrm{ng} \cdot \mathrm{m}^{3}$ (Environmental Impact Assessment Report, 2016). Average annual PM10 concentration of $53 \mu \mathrm{g} \cdot \mathrm{m}^{3}$ recorded in Rybnik Forest District exceeded the permissible standard $\left(20 \mu \mathrm{g} \cdot \mathrm{m}^{3}\right)$ and as same as average annual concentrations of PM2.5, reaching the result of $26 \mu \mathrm{g} \cdot \mathrm{m} 3$ exceeded the permissible standard $\left(10 \mu \mathrm{g} \cdot \mathrm{m}^{3}\right)$ (WHO, 2005).

The study areas were selected during field observations. The research covered stands of similar age, onestory structure and the same canopy density. The age of the stands is 80 years. Three coniferous stands, the main species of which was Scots pine (Pinus sylvestris L.), three mixed stands, formed by Scots pine (Pinus sylvestris L.) and Pedunculate oak (Quercus robur L.), and three deciduous stands, formed by Pedunculate oak (Quercus robur L.), were selected for the study. The stands grew on soils with a similar grain size, the average sand content was $81 \%$, silt content $16 \%$ and clay content $3 \%$. The samples were taken from the organic horizons (Of, Oh, Ofh), humus mineral horizons (AEes, A) and mineral horizons (B) (Fig. 3). In order to determine enzyme activity, microbial biomass and PAH content, fresh samples of natural moisture were taken, sifted through a sieve $(\varnothing 2 \mathrm{~mm})$ and stored at $4^{\circ} \mathrm{C}$ in the dark before analysis.

\section{Laboratory analysis}

The particle size distribution was determined using laser diffraction (Analysette 22, Fritsch, Idar-Oberstein, Germany). The soil $\mathrm{pH}$ was determined in $\mathrm{H} 2 \mathrm{O}$ and $\mathrm{KCl}$ using the potentiometric method. $\mathrm{C}$ and $\mathrm{N}$ were measured using an elemental analyser (LECO CNS TrueMac Analyzer Leco, St. Joseph, MI, USA). The concentration of calcium, potassium, magnesium and sodium was determined by an ICP (ICP-OES Thermo iCAP 6500 DUO, ThermoFisher Scientific, Cambridge, U.K.). Available phosphorus was measured using a Bray-Kurtz method.

The PAHs were determined in $10 \mathrm{~g}$ of each soil sample, extracted using $70 \mathrm{ml}$ of 2 -propanol. The samples were centrifuged (4500 rpm, $5 \mathrm{~min}$ ) and the supernatant collected. The supernatants were extracted to the solid phase $(5 \mathrm{ml} / \mathrm{min}$ ) using solid-phase extraction (CHROMABONDß $\mathrm{CN} / \mathrm{SiOH}$ ). The residue was dissolved in acetonitrile and analysed using high-pressure liquid chromatography (HPLC) with a Dionex UltiMate 3000 HPLC system, equipped with a fluorescence detector and a Dionex UltiMate 3000 Column Compartment C18 $5 \mu \mathrm{m}$ with a 4.6x100-mm HPLC column. The mobile phases were water (A) and acetonitrile (B) at a flow rate of $1 \mathrm{ml} / \mathrm{min}$. Based on the standard PAH Calibration Mix (CRM 47940) at 
a concentration of $10 \mu \mathrm{g} / \mathrm{ml}$, calibration solutions at different concentrations (i.e. $0.1,0.2,0.5,1$ and 2 $\mu \mathrm{g} / \mathrm{ml}$ ) were prepared. Each prepared solution was placed into the chromatography column, the chromatograms obtained being used to produce a calibration curve. The soil samples were then analysed in triplicate. After every nineth analysis, a control sample (a calibration solution with a concentration of $0.1 \mu \mathrm{g} / \mathrm{ml}$ ) was injected. Naphthalane [Nft], Acenapthene [Ace], fluoren [Flu], phenanthrene [Phe], antracen [Ant], fluoranthene [Flt], pyrene [Pyr], benzo(a)anthracene [BaA], chrysene [Chr], benzo(k)fluoranthene $[\mathrm{BkF}]$, benzo(b)fluoranthene $[\mathrm{BbF}]$, benzo(a)pyrene $[\mathrm{BaP}]$, dibenzo(ah)anthracene [DBahAnt] indeno(1,2,3$\mathrm{c}, \mathrm{d})$ pyren $[\mathrm{IcdP}]$, and benzo(g,h,i)perylene $[\mathrm{BghiP}]$ were determined. The activity of extracellular enzymes ( $\beta$-D-cellobiosidase $[\mathrm{CB}], \beta$-glucosidase $[\mathrm{BG}]$, xylanase $[\mathrm{XYL}], \mathrm{N}$-acetyl- $\beta$-D-glucosaminidase $[\mathrm{NAG}]$, phosphatase $[\mathrm{PH}]$ was determined using fluorogenically-labeled substrates (Pritsch et al., 2004; Turner, 2010; Sannaullah et al., 2016).

The fluorescence was measured on a multidetection plate reader (SpectroMax), with excitation at a wavelength of $355 \mathrm{~nm}$ and emission at $460 \mathrm{~nm}$. The dehydrogenase activity (DH) was determined using Lenhard's method according to the Casida procedure (Alef \& Nannipieri, 1995). For the determination of microbial biomass $\mathrm{C}$, microbial biomass $\mathrm{N}$ and microbial biomass $\mathrm{P}$, the fumigation and extraction method was used (Jenkinson \& Powlson, 1976; Vance et al., 1987).

Physical separation of soil organic matter fractions was performed using the method described by Sohi et al. (2001). A sample of soil (15 g) was placed in a $200-\mathrm{ml}$ centrifuge tube and $90 \mathrm{ml}$ of NaI $(1.7 \mathrm{~g} \mathrm{~cm}-3)$ was added. Each tube was gently shaken for $1 \mathrm{~min}$ and centrifuged for $30 \mathrm{~min}$. The free light fraction (fLF) was removed using the pipette and collected on a glass fiber filter. The soil remaining at the bottom of the centrifuge tubes was mixed with another portion of $90 \mathrm{~mL}$ of NaI and subjected to sonication (60 watts for $200 \mathrm{~s}$ ) to destroy aggregates. After centrifugation, the matter released from aggregates occluded light fraction $(\mathrm{oLF})$ was collected on glass fiber filter. The remaining fraction was assumed to consist of mineral associated fraction (MAF) of SOM. After drying $\left(40{ }^{\circ} \mathrm{C}\right)$, the subsamples of different fraction were weighted and analyzed for CfLF, CoLF, and CMAF, respectively using an LECO CNS True Mac Analyzer (Leco, St. Joseph, MI, USA).

\section{Statistical anaylsis}

The Pearson correlation coefficients for the soil characteristics were calculated. Principal component analysis (PCA) was used to evaluate the relationships between the soil properties and PAH content. Analysis of variance was employed to assess the differences between the average values of the soil properties and PAH content. Properties of different humus types were compared using a parametric honestly significant difference (HSD) test. The multiple regression method was used to develop models describing the relationship between the PAH content and soil properties. All the statistical analyses were performed using statistical package $\mathrm{R}$ (R Core Team 2020) and R Studio (RStudio Team 2020).

\section{Results}

\section{Physicochemical properties}

Soil pH ranged from 3.57 to 3.98 and increased with soil depth (Tab. 1). Soils with pine stands were characterized by the lowest $\mathrm{pH}$. Pine-oak stands were characterized by a higher $\mathrm{pH}$, while oak stands were characterized by the highest $\mathrm{pH}$. The content of carbon, nitrogen and phosphorus was statistically higher in the organic horizons of the tested soils (Tab. 1). In the mineral horizons, there was a clear decrease in C, N and $\mathrm{P}$ content. The highest content of organic carbon, i.e., $33.32 \%$, was recorded in the organic horizons of pine stand soils. Mixed pine-oak stands were characterized by a lower organic carbon content of $23.23 \%$ and the lowest $\mathrm{C}$ content, i.e., $20.18 \%$ was found in oak stands. The highest nitrogen content was recorded in organic horizons of pine stand soils (1.42\% in the Of horizon and $1.06 \%$ in the Oh horizon). Lower nitrogen content was recorded in the soils of pine-oak stand (1.04\% in the Ofh horizon) and the lowest nitrogen content was recorded in the organic horizons of oak stand soils (1.00\%). The $\mathrm{C} / \mathrm{N}$ ratio showed the highest values in pine stand soils, lower in pine-oak stand soils and the lowest in oak stand soils. The sum of alkaline cations reached statistically higher values in the organic horizons of the tested soils (Tab. 1). 


\section{Biochemical parameters}

In all stand variants, organic soil horizons were characterized by significantly higher enzymatic activity (Tab. 2 ). The activity of enzymes decreased significantly with the depth of soil profile. In general, the highest activity of the studied extracellular enzymes in terms of percentage of organic carbon was found in organic horizons, especially organic horizons of pine stands. In the case of DH and NAG activity, the highest values were recorded in the organic horizons of oak stand soils. In the case of mineral humus horizons, the highest activity of DH and PH was recorded in the oak stand soils (Tab. 2). As in the case of enzymatic activity, significantly higher microbiological biomass of $\mathrm{C}$ and $\mathrm{N}$ was recorded in surface soil horizons (Tab. 2). The highest MBC was recorded in the top horizon of pine stands $\left(2414.77 \mu \mathrm{g} \cdot \mathrm{kg}^{-1}\right)$, while the second one was recorded in the top horizons of oak stands $\left(2296.67 \mu \mathrm{g} \cdot \mathrm{kg}^{-1}\right)$, and the lowest MBC z was noted in the soils of pine-oak stands $\left(2097.24 \mu \mathrm{g} \cdot \mathrm{kg}^{-1}\right)$. The highest MBN was recorded in topsoil levels of oak stands (461.25 $\left.\mu \mathrm{g} \cdot \mathrm{kg}^{-1}\right)$, lower in pine-oak stand soils $\left(421.62 \mu \mathrm{g} \cdot \mathrm{kg}^{-1}\right)$, and the lowest in pine stand soils $\left(335.18 \mu \mathrm{g} \cdot \mathrm{kg}^{-1}\right)$ (Tab. 2). In mineral humus horizons, the highest MBC and MBN was recorded in oak stand soils and the lowest in pine stand soils (Tab. 2).

\section{Soil organic matter fraction parameters}

Statistically significant highest average $\mathrm{C}$ and $\mathrm{N}$ contents in the free light fraction were found in the top horizons of the soils studied (Tab. 3). The highest $\mathrm{C}$ and $\mathrm{N}$ content in the free light fraction was recorded in the organic horizon of pine stand soils (266.30 and $7.99 \mathrm{~g} \cdot \mathrm{kg}^{-1}$, respectively), the surface horizons of pine-oak stands were characterized by lower values $\left(134.19 \mathrm{~g} \cdot \mathrm{kg}^{-1}\right.$ and $5.10 \mathrm{~g} \cdot \mathrm{kg}^{-1}$, respectively) and surface horizons of oak stands by the lowest ones $\left(105.22 \mathrm{~g} \cdot \mathrm{kg}^{-1}\right.$ and $5.05 \mathrm{~g} \cdot \mathrm{kg}^{-1}$, respectively). Significantly higher mean C and $\mathrm{N}$ contents in the aggregate-occluded light fraction were recorded in the humus mineral horizons of the soils studied (Tab. 3). The highest content of $\mathrm{C}_{\mathrm{OLF}}$ and $\mathrm{N}_{\mathrm{OLF}}$ was found in the Oh horizon of pine stand soil (13.87 and $0.58 \mathrm{~g} \cdot \mathrm{kg}^{-1}$, respectively). In the case of $\mathrm{C}$ and $\mathrm{N}$ of the mineral associated fraction, the highest values were determined in the humus horizon of mineral soils of oak and pine-oak stands (Tab. 3).

\section{Polycyclic aromatic hydrocarbons content}

The highest PAHs content was recorded in organic soil horizons of all stand variants (Tab. 3, Fig. 4, Fig. 5). The PAHs content decreased with soil depth, regardless of the stand variant. The highest amount of PAHs in organic horizons was recorded in pine stand soils $\left(4816.13 \mu \mathrm{g} \cdot \mathrm{kg}^{-1}\right.$ in Of and $2793.60 \mu \mathrm{g} \cdot \mathrm{kg}^{-1} \mathrm{in} \mathrm{Oh}$ horizon). In the Ofh horizon of pine-oak stand soils, the average PAH content was $3087.09 \mu \mathrm{g} \cdot \mathrm{kg}^{-1}$ and in oak stand soils it was $2936.20 \mu \mathrm{g} \cdot \mathrm{kg}^{-1}$ (Tab. 3). In the surface horizons of pine and pine-oak stands soils, a clear domination of 3- and 4-ring PAHs was noted (Fig. 4). In the case of oak stand soils, 4-ring PAHs dominated, followed by 3 and 5-ring PAHs. The highest mean content of 3-ring PAHs in the organic soils levels was noted in case of fluorine and phenanthrene (Fig. 5). In turn, fluoranthene, pyrene and chrysene showed the highest values among 4-ring PAHs. For 5- and 6-ring PAHs, the highest values were reached by benzo(b)fluoranthene and ideno(c,d)pyrene, respectively.

\section{Corelations}

In the soils studied, the activity of enzymes strongly correlated with carbon and nitrogen content, in the case of $\mathrm{CB}, \mathrm{BG}, \mathrm{XYL}$ and $\mathrm{PH}$ it was a positive relationship. In the case of most of enzymes studied, statistically significant correlations with PAH content were noted, apart from $\mathrm{DH}$ and $\mathrm{CB}$ activity (Tab. 4). Also a positive relationship between the amount of accumulated PAHs and $\mathrm{C}_{\mathrm{fLF}}, \mathrm{N}_{\mathrm{fLF}}$ and $\mathrm{C}_{\mathrm{MAF}}$ was found in the soils studied (Tab. 4). A significant positive correlation between PAH content and the amount of organic carbon was clearly shown (Fig. 5), especially in pine stands soils, where PAHs increase exponentially with the amount of organic carbon. (Fig. 6). Multiple regression analysis confirmed relationships between PAHs content and the $\mathrm{C}$ of light and heavy fraction of soil organic matter. Multiple regression models explained $84 \%$ of the variance in PAH content (Tab. 5).

Factors 1 and 2, distinguished in the PCA analysis, explain a total of $66.8 \%$ of the variance of properties of the tested soils (Fig. 7). The PCA analysis confirms the negative correlation between PAH content and 
$\mathrm{pH}$ of the tested soils. The PAHs content positively correlated with $\mathrm{C}_{\mathrm{fLF}}$ and $\mathrm{N}_{\mathrm{fLF}}$ (Fig. 7). The PCA analysis confirms a higher PAHs content in the organic horizons of the soils studied, where a lower $\mathrm{pH}$ and a higher $\mathrm{C}$ content were observed. Mineral horizons are associated with a higher content of $\mathrm{C}$ and $\mathrm{N}$ of the aggregate-occluded light fraction and mineral associated fraction (Fig. 7).

\section{Discussion}

The obtained results confirm the hypothesis of significant impact of stand species composition on the amount and quality of soil organic matter supplied to the soil and on acidification, and consequently on PAHs accumulation in forest soils. In all cases of the investigated soils, the amount of PAHs accumulated in organic horizons indicated the third, moderate degree of soil contamination $\left(1000-5000 \mu \mathrm{g} \cdot \mathrm{kg}^{-1}\right)$ according to the classification proposed by Maliszewska-Kordybach (1996). The highest average accumulation of PAHs in organic horizons was recorded in soils of pine stands, lower in soils of mixed pine-oak stands and the lowest in soils of oak stands. At the same time, the soils with the highest PAHs accumulation were characterized by strong acidification and less decomposed organic matter. The quality and quantity of soil organic matter is an effect of the stand species composition, which has already been described by other authors (Jandl et al., 2007; Schulp et al., 2008; Vesterdal et al., 2008; Zhang et al., 2008). The share of deciduous species in the stand improves the biogeochemical cycles of the matter by providing nutrients (Augusto et al., 2015; Ammer, 2019). Coniferous species, especially pine, provide organic fall to the soil, which acidifies the top soil horizons. As a result of the influence of coniferous species, the processes of microbiological decomposition of the fallen organic matter on the soil surface are generally slower (Schulp et al., 2008; Eisalou et al., 2013; Magh et al., 2018). Deciduous species provide the soil with carbon substrates and nutrients used by microorganisms in the decomposition processes through the fall of litter and root systems (Błońska, 2015; Błońska et al. 2021). The beneficial effect of deciduous species on the topsoil was reflected in higher $\mathrm{pH}$ value and higher content of alkaline cations. It was also observed that the share of deciduous species had a significant positive effect on the biochemical properties of soils expressed by enzymatic and microbiological activity of biomass, which was reflected in organic matter decomposition processes and PAHs biodegradation potential. An increased share of deciduous tree species that co-create the stand leads to the relocation of carbon to ground biomass, resulting in a beneficial increase in nutrient utilization efficiency compared to coniferous monocultures (Epron et al., 2013). An increased PAHs accumulation capacity in organic horizons of coniferous stand soils is also due to the effect of the assimilation of pollutants in the atmosphere through the presence of assimilation apparatus throughout the growing season (Hill et al., 2002; Peng et al., 2012). An increased PAHs accumulation in coniferous forest soils can also be explained by the presence of wax and lipids on the needle surface, which are able to absorb and accumulate lipophilic PAHs present in the contaminated atmosphere (Li et al., 2017).

Our research confirmed the importance of the fraction of soil organic matter in the accumulation of PAHs in forest soils. In our study, the PAHs content was closely related to the amount of organic carbon and nitrogen of free light fraction of soil organic matter. According to Cachada et al., (2018), the amount and quality of soil organic matter and its fractions are the factor controlling the accumulation of PAHs in soils. Soils of pine stands are characterized by a higher proportion of light fraction of soil organic matter, which is due to the slowdown of decomposition processes. Additionally, high value of $\mathrm{C}$ to $\mathrm{N}$ ratio of light fraction in soils of pine stands confirms weaker decomposition of organic residues. In the case of soils of oak stands, a significantly lower $\mathrm{C} / \mathrm{N}$ ratio of light fraction of soil organic matter was recorded. The light fraction present in the soil is formed by partially decomposed plant residues, animal remains in the intermediate stage of decomposition between stabilized carbon (Błońska, 2015). According to Li et al., (2014), the organic fraction has stronger sorption properties compared to the mineral fraction. The biodegradation efficiency of PAHs by microorganisms is related to the bioavailability of compounds dissolved in the soil solution (Mackay et al., 2001). According to Jastrow et al. (2007), the biological activity of soils is regulated by the structures of organic matter, and in particular is determined by the size of soil aggregates. The relationship between $\mathrm{C}$ and $\mathrm{N}$ of free light fraction of organic matter and PAHs content and enzymatic activity in soils has been reported. Strong sorption of PAH compounds within the organic matter structures reduces bioavailability as well as desorption and diffusion of pollutants by microorganisms (Ukalska-Jaruga et al., 2015). 
According to Oleszczuk et al. (2007), strong sorption of PAH compounds occurs under low pH conditions, which is characteristic for soils with coniferous stands in our study. The low soil pH may result from a significant amount of humic and fulvic acids (Maliszewska-Kordybach et al., 2010), which significantly reduce the bioavailability of organic matter and PAHs in soil solution (Haynes, 2005). Strongly absorbed, soil-accumulated PAH compounds inaccessible to microorganisms are subject to aging process (Zhang et al., 2011). Ni et al. (2008) claim that an effective method of bioremediation of soils contaminated with PAHs is to reduce the content of free light fraction of organic matter. Wilson et al. (1993) claim that the bioremediation method by reducing the free light fraction of organic matter is only effective with respect to low molecular weight PAHs. However, our research also confirms the effect of light fraction organic matter reduction on high molecular weight PAHs due to the beneficial effect of nutrients supplied to the soil by oak stands. The contribution of oak forming a stand can be an effective factor in the process of natural soil bioremediation and elimination of toxic soil contamination levels especially for stands exposed to intensive industrial emissions. However, more research is needed on the impact of other deciduous species forming the stands on the reduction of PAHs in the soil through beneficial effects on the amount and quality of soil organic matter and the amount of nutrients.

In our study we noted a strong positive relationship of enzymatic activity with organic carbon and PAHs content in soils. The lack of limitation of enzyme activity in soil samples with high PAHs content can be explained by the masking effect of soil organic matter. Strong affinity of soil organic matter to PAHs and at the same time high enzymatic activity in samples with high content of organic carbon explains the obtained relationships. Similar results were obtained in the case of relations between enzyme activity and heavy metal content with simultaneous high accumulation of organic carbon (Lasota et al. 2020).

\section{Conclusions}

Our research confirms the importance of stand species composition in PAHs accumulation in forest soils. The stand species composition influences the amount and quality of soil organic matter and acidification, which in turn is reflected in soil biochemical activity and decomposition of organic pollutants. A significant influence of deciduous species on the surface properties of soil levels and consequently on the PAHs content was found. The soils of oak stands were characterized by the lowest accumulation of PAHs with high biochemical activity expressed by enzyme activity and microbiological biomass. Pine stand soils are strongly acidified, the decomposition of soil organic matter is slowed down, resulting in a high accumulation of PAHs. Our results confirmed the importance of fractional composition of soil organic matter in PAHs accumulation. The free light fraction of soil organic matter and the mineral associated fraction are of greatest importance in PAHs accumulation.

\section{Hosted file}

References.pdf available at https://authorea.com/users/395929/articles/509049-stand-speciescomposition-as-a-key-factor-determining-the-amount-of-polycyclic-aromatic-hydrocarbonspahs-in-forest-soils

\section{Hosted file}

Tables.pdf available at https://authorea.com/users/395929/articles/509049-stand-speciescomposition-as-a-key-factor-determining-the-amount-of-polycyclic-aromatic-hydrocarbonspahs-in-forest-soils

\section{Hosted file}

Figures.pdf available at https://authorea.com/users/395929/articles/509049-stand-speciescomposition-as-a-key-factor-determining-the-amount-of-polycyclic-aromatic-hydrocarbonspahs-in-forest-soils

\section{Hosted file}


Credit Author Statement.pdf available at https://authorea.com/users/395929/articles/509049stand-species-composition-as-a-key-factor-determining-the-amount-of-polycyclic-aromatichydrocarbons-pahs-in-forest-soils 